\title{
Canada's Public Health Agency: Bound and gagged?
}

Published at www.cmaj.ca on Mar. 16, 2004.

T his Journal has repeatedly called for federal leadership in public health, ${ }^{1}$ leadership that would guide us through crises such as BSE, Walkerton ${ }^{3}$ and SARS $^{4,5}$ and that would ensure the fundamentals of health protection, including national surveillance and a national vaccination strategy. ${ }^{6}$ We have not been alone in advocating a national public health agency. Nothing is more obvious and more urgently needed than a national body that is independent of politicians and bureaucrats and dedicated solely to protecting and enhancing the health of the public. An agency that will lead, not follow.

At the helm of change, Carolyn Bennett, the Minister of State for Public Health, is charged with "establish[ing] a strong and responsive public health system." "Yet, days before the federal budget is brought down, we find the minister waiting for comments to a discussion paper $^{8}$ that could only have been written by senior bureaucrats who have but a timorous and vague concept of what public health is and whose primary focus is on "opening a dialogue on public health issues" and keeping the new agency firmly within their control. "The agency," we are informed, "would ... operate within the Health Canada portfolio."

Hello. In the light of widespread outbreaks of old pathogens and the now almost monthly arrival of new ones from around the world, we do not need the procrastinations of yet another federal subdepartment of some other subdepartment reporting to a distant associate of some deputy minister. We need leadership. We need independence. We need an agency that is adequately funded and a chief public health officer who can report directly to the public without the filters applied by bureaucrats and communications officers.

There is no doubt that, to be effective, public health must build consensus among often-competing public (and private) institutions, including government. As the SARS epidemic in Toronto taught us, cooperation among federal, provincial and local health agencies is not automatic.? Equally important, however, is a public consensus based on a coherent understanding of the facts. ${ }^{10}$ This larger consensus cannot be achieved by endless federal-provincial doughnut-and-coffee meetings in hotel meeting rooms, as Health Canada and the provinces have tried to do for decades and failed, dismally, with tragic results.
The rapid succession of public health emergencies has convinced the public that they are inadequately protected and that they live and work in environments that require risk monitoring. Politicians have also understood. Minister Bennett has the goal correctly identified, and the government has made a public commitment to it in the Throne Speech. Provincial politicians are also in agreement with the creation of the new federal agency. Yet, for all that, the health ministers in Ottawa and their provincial counterparts risk underestimating the entrenched sluggishness of their own bureaucracies.

Ontario, for example, recently attempted to shore up its spotty public health system by appointing the very competent Dr. Sheela Basrur to replace the former Chief Medical Officer of Health. Wisely, Provincial Premier McGuinty placed her on a higher stool than her predecessor - she reports directly to the Minister of Health and Long-Term Care. However, Dr. Basrur remains hobbled by resources (for a population of 11.4 million) that are not much more than those of a small doughnut franchise.

Minister Bennett and her cabinet colleagues must extricate themselves from the inertia of bureaucracy and discussion papers. They must take the bold step needed to create a truly independent national public health agency. The appointment of the chief public health officer must be credible. And the budget, to be revealed shortly, must rapidly bring to the agency the estimated $\$ 1$ billion that it will need to do the job. ${ }^{9}-C M A 7$

\section{References}

1. A Canadian agency for public health: If not now, when? [editorial]. CMAf $2003 ; 169(8): 741$

2. From nannyism to public disclosure: the BSE inquiry report [editorial]. CMA7 2001;164(2):165.

3. Public health on the ropes [editorial]. CMA7 2002;166(10):1245.

4. Lessons from SARS [editorial]. CMA7 2003;168(11):1381.

5. SARS: the struggle for containment [editorial]. CMAf 2003;168(10):1229.

6. A patchwork policy: vaccination in Canada [editorial]. CMA7 2003;168(5):533.

7. Canada House of Commons Debates (Hansard). Speech from the Throne. 37th Parliament, 3rd sess, 2004, vol 139, no 001.

8. Bennett C. Strengthening the pan-Canadian public bealth system [discussion paper]. Ottawa: Health Canada;2004. Available: www.hc-sc.gc.ca/english /pha/strengthening.html (updated 2004 Feb 27; accessed 2004 Mar 15).

9. National Advisory Committee on SARS and Public Health. Learning from SARS: renewal of public health in Canada. Ottawa: Health Canada; 2003. Cat no H21-220/2003E. Available: www.hc-sc.gc.ca/english/protection/warnings /sars/learning.html (accessed 2004 Mar 15).

10. Public health, public persuasion [editorial]. CMA7 2000;162(7):961. 